\title{
Racial Discrimination in Employment Under the Civil Rights Act of 1866
}

When the Supreme Court granted certiorari in the case of Jones $v$. Alfred $H$. Mayer Co., ${ }^{1}$ it undoubtedly came as a surprise to many lawyers to learn from the popular press that two wide-sweeping statutory provisions dealing with civil rights had gone virtually unused for a century. The two provisions, originating in section 1 of the Givil Rights Act of $1866,{ }^{2}$ are presently worded in the following form in Title 42 of the U.S. Code:

1981. All persons within the jurisdiction of the United States shall have the same right in every State and Territory to make and enforce contracts, to sue, be parties, give evidence, and to the full and equal benefit of all laws and proceedings for the security of persons and property as is enjoyed by white citizens, and shall be subject to like punishments, pains, penalties, taxes, licenses, and exactions of every kind, and to no other.

1982. All citizens of the United States shall have the same right, in every State and Territory, as is enjoyed by white citizens thereof to inherit, purchase, lease, sell, hold, and convey real and personal property.

On their face these two provisions appear to prohibit acts of racial discrimination by private individuals in a broad field of activities. Both provisions were rendered ineffectual, however, by cases holding that they were never intended to reach private acts of discrimination, ${ }^{3}$ were intended to implement the fourteenth amendment which required some degree of "state action,"4 and could not be supported by

1392 U.S. 409 (1968).

2 Act of 9 April, 1866, ch. 31, 14 Stat. 27 (1866).

3 This interpretation was based on the argument that $\S 2$ of the 1866 act was intended to enforce the rights protected by $\S 1$. Since $\S 2$ applied only to actions "under color of any law, statute, regulation, or custom," then $\$ 1$ must be similarly restricted. See Jones v. Mayer, 392 U.S. at 454 (dissenting opinion); Civil Rights Cases, 109 U.S. 3, $16-17$ (1883).

4 E.g., Hurd v. Hodge, 334 U.S. 24, 31-32 (1948); Virginia v. Rives, 100 U.S. 313,317 (1879). 
the thirteenth amendment which was concerned only with the abolition of slavery. ${ }^{5}$

Jones v. Mayer brought the 1866 Civil Rights Act back to life. Mr. and Mrs. Jones, unsuccessful in their effort to purchase a home in a subdivision near St. Louis, filed suit in the federal courts on the grounds that the developers had refused to sell to them for the sole reason that Joseph Lee Jones is a Negro. ${ }^{6}$ The complaint, based in part on 42 U.S.C. $\$ 1982$, was dismissed by the trial court; ${ }^{7}$ the Circuit Court of Appeals affirmed. ${ }^{8}$ The Supreme Court declined this opportunity to continue its expansion of the scope of the fourteenth amendment $^{9}$ and stated its holding in these words:

We hold that $\S 1982$ bars all racial discrimination, private as well as public, in the sale or rental of property, and that the statute, thus construed, is a valid exercise of the power of Congress to enforce the Thirteenth Amendment. ${ }^{10}$

The case raises a number of important questions as to the scope both of congressional powers under the thirteenth amendment and of existing legislation long dormant. This comment considers one of those questions-whether employment discrimination suits may be brought under 42 U.S.C. $\S 1981 .^{11}$ The Jones case can be accepted as

5 E.g., Corrigan v. Buckley, 271 U.S. 323, 330 (1926); Hodges v. United States, 203 U.S. 1, 16-18 (1906).

6392 U.S. at 412.

7 The District Court found no state involvement in the case and held that under the federal civil rights statutes "there must be some substantial involvement of the state or one acting under the color of its authority. . . " Jones v. Alfred H. Mayer Co., 255 F. Supp. 115, 120 (E.D. Mo. 1966).

8 Jones v. Alfred H. Mayer Co., 379 F.2d 33 (8th Cir. 1967).

9 See Katzenbach v. Morgan, 384 U.S. 641 (1966); United States v. Guest, 383 U.S. 745 (1966). Extensive arguments were set out in the briefs asserting that prohibition of private acts of discrimination could be supported by the fourteenth amendment. See petitioner's Brief at 23-39. The amicus curiae brief for the United States devotes very little consideration to thirteenth amendment support for $\$ 1982$, giving primary emphasis to the argument that the fourteenth amendment authorizes such legislation. For an excelIent discussion of the implications of the Morgan case for legislation directed at private discrimination, see Cox, Foreword: Constitutional Adjudication and the Promotion of Human Rights, 80 HARv. L. Rev. 91 (1966).

10392 U.S. at 413 (emphasis in text). The case has already been subject to considerable comment in the law reviews. See, Kohl, The Civil Rights Act of 1866 and the Supreme Court in 1968: Its Hour Come Round at Last, 55 VA. L. Rev. 272 (1969); Casper, Jones v. Mayer: Clio, Bemused and Confused Muse, 1968 Sup. Cr. Rev. 89; Morris \& Powe, Constitutional and Statutory Rights to Open Housing, 44 WASH. L. REv. 1, 60-75 (1968); Note, Open Housing-A Reality in 1968?, 3 Surf. L. Rev. 149 (1968); Note, 20 CASE W. Res. L. Rev. 448 (1969); Note, 53 Mrns. L. Rev. 641 (1969); Note, 41 U. Colo. L. Rev. 152 (1969); Note, 2 CReighton L. Rev. 185 (1968); Note, Ford. L. Rev. 277 (1968); I4 VILL. L. REv. 116 (1968).

11 An important subsidiary question that is beyond the scope of this comment is 
authority for two propositions: that the thirteenth amendment authorizes legislation against private acts of discrimination, and that the Civil Rights Act of 1866 was intended to prohibit discriminatory acts by private individuals. Several issues remain which must be resolved before the primary question can be answered. What support is there for the position that employment discrimination is prohibited by the 1866 act, as represented today by section 1981? Did passage of Title VII of the Givil Rights Act of $1964^{12}$ have the effect of repealing part of the coverage of section 1981? What difference does it make whether section 1981 is available as the potential source of a cause of action?

\section{The Scope of Section 1981 Prior to 1964}

The language of section 1981 would appear to encompass employment discrimination suits. The relationship of employer and employee is undeniably contractual in nature. ${ }^{13}$ It would also seem that a Negro offered different contract terms because of his race is being denied "the same right" as whites to make employment contracts. Thus, the statute could be interpreted to prohibit such practices as discriminatory wage and promotion policies. Since the limited case law offers little assistance to interpretation, the statute's historical background and legislative history must be considered in some detail.

\section{A. The Civil Rights Act of 1866}

At the close of the Civil War it was apparent that, while emancipation had been proclaimed, the South was not prepared to abandon the labor system which had supported its economy for so long. ${ }^{14}$ When

what discrimination is prohibited by the statute. Because of the language of the statute - "the same right ... as is enjoyed by white citizens"-and because the statute presently relies on the thirteenth amendment for its constitutionality, it will be assumed throughout the following discussion that $\S 1981$ prohibits only racial discrimination. Certainly an argument could be made for a broader interpretation of the statute based on the fourteenth amendment line of reasoning suggested by note 9 supra.

1242 U.S.C. $\$ 2000 \mathrm{e}$ to $\S 2000 \mathrm{e}-15$ (1964).

13 Whether $\S 1981$ might also cover unions and employment agencies, as does Title VII of the 1964 act, is beyond the scope of this comment. The one post-Jones case which has upheld an employment discrimination suit under $\$ 1981$ was brought against a union. Dobbins v. Local 212, IBEW, 292 F. Supp. 413 (S.D. Ohio 1968) (alternative holding).

14 Aside from the assumption that the negro will not work without physical compulsion, there appears to be another popular notion prevalent in the south, which stands as no less serious an obstacle in the way of a successful solution of the problem. It is that the negro exists for the special object of raising cotton, rice, and sugar for the whites....

REPORT of C. Schurz, S. EXEc. Doc. No. 2, 39th Cong., Ist Sess. at 21 (1865) (emphasis in text). 
the war ended the President commissioned Brigadier General Carl Schurz to tour the five most war-ravaged states to report on conditions there and suggest measures to overcome some of the problems left by the war. He concluded that

It is, indeed, not probable that a general attempt will be made to restore slavery in its old form, on account of the barriers which such an attempt will find in its way; but there are systems intermediate between slavery as it formerly existed in the south, and free labor as it exists in the north, but more nearly related to the former than to the latter, the introduction of which will be attempted. ${ }^{15}$

It was in this setting that the Civil Rights Act of 1866 was introduced, debated, and enacted into law. Just five days after official certification of the thirteenth amendment Senator Trumbull introduced S. No. 61, which was to become the 1866 Civil Rights Act.18 Section 1, as enacted, reads as follows:

Be it enacted by the Senate and House of Representatives of the United States in Congress assembled, That all persons born in the United States and not subject to any foreign power, excluding Indians not taxed, are hereby declared to be citizens of the United States; and such citizens, of every race and color, without regard to any previous condition of slavery or involuntary servitude, except as a punishment for crime whereof the party shall have been duly convicted, shall have the same right, in every State and Territory in the United States, to make and enforce contracts, to sue, be parties, and give evidence, to inherit, purchase, lease, sell, hold, and convey real and personal property, and to full and equal benefit of all laws and proceedings for the security of persons and property, as is enjoyed by white citizens, and shall be subject to like punishment, pains, and penalties, and to none other, any law, statute, ordinance, regulation, or custom, to the contrary notwithstanding. ${ }^{17}$

In addition to the Schurz report, extensive evidence was available to Congress which indicated the state of affairs in the South. Proponents of the Civil Rights Act drew on this information to illus-

15 Id. at 32. Schurz described one such system by which certain South Carolina planters intended to keep "free" labor under permanent control "by introducing into the contracts provisions leaving only a small share of the crops to the freedmen, subject to all sorts of constructive charges, and then binding them to work off the indebtedness they might incur." Id. at 22.

16 Cong. Globe, 39th Cong,, 1st Sess. 129 (1866) [hereinafter cited as Cong. Grobe].

1714 Stat. 27 (1866). 
trate practices which the bill was intended to eliminate. 18 While Congress did not debate the scope of the term "contracts," the one specific contract which was referred to and discussed was the employment contract. The bill's supporters believed that freedom would be valueless to men not assured an equal opportunity to bargain for their labors. ${ }^{19}$ In the words of Representative Lawrence,

It is idle to say that a citizen shall have the right to life, yet deny him the right to labor, whereby alone he can live. It is a mockery to say that a citizen may have a right to live, and yet deny him the right to make a contract to secure the privilege and the rewards of labor. ${ }^{20}$

On March 2 Representative Windom obtained the floor for the purpose of explaining the scope of the bill. He succinctly stated his understanding of section 1 :

Its object is to secure to a poor, weak class of laborers the right to make contracts for their labor, the power to enforce the payment of their wages, and the means of holding and enjoying the proceeds of their toil. ${ }^{21}$

Such statements make clear that, insofar as S. No. 61 was intended to prohibit private acts of racial discrimination, it was intended to end employment discrimination.

B. Enforcement Act of 1870

Neither section 1981 nor section 1982 is taken verbatim from the 1866 act. This creates a small, but troublesome, complication in studying the legislative history of section 1981. These two sections are actually sections 1977 and 1978 of the Revised Statutes of 1874, an official

18 For example, Representative Windom introduced a letter from Colonel deGauss to Major General Howard of the Freedmen's Bureau which stated that in Texas "a freedman is not allowed to hire out without written permission from his former master . . . Id. at 1160. Part of Major General Terry's testimony before the Reconstruction Committee was entered into the record, in which he indicated that many persons in Virginia treated the freedmen harshly and "seek to obtain their services without just compensation, and to reduce them to a condition which will give to the former masters all the benefits of slavery and throw upon them none of its responsibilities." $I d$. at 1833 .

19 Planters combine together to compel them to work for such wages as their former masters may dictate, and deny them the privilege of hiring to anyone without the consent of the master; and in order to make it impossible for them to seek employment elsewhere, the pass system is still enforced... Do you call that man free who cannot choose his own employer, or name the wages for which he will work?

Id. at 1160 (Representative Windom).

$20 I d$. at 1833 .

21 Id. at 1159 . 
codification of all prior acts. While R.S. 1978 is acknowledged to originate in the 1866 act, the origin of R.S. 1977 is cited as the Act of 31 May, $1870 .^{22}$ In fact, R.S. 1977 appears to have been taken almost verbatim from section 16 of the 1870 act.

Two sections of the 1870 act are important to this discussion. Section 16 contained the essence of R.S. 1977 and R.S. 2164, prohibiting discriminatory state taxes on immigrants. Section $18^{23}$ expressly incorporated and reenacted the 1866 Givil Rights Act. Both the Senate opponents of the 1866 act and President Andrew Johnson in his veto of the bill ${ }^{24}$ had argued that many of its provisions were beyond the constitutional power of Congress to enact. Section 18 of the 1870 act was intended to insure that the 1866 act was supported by both the thirteenth and fourteenth amendments. ${ }^{25}$

In 1866 Congress had already recognized the need to reorganize and consolidate the federal statutes. On June 27, 1866, an act was passed authorizing the appointment of a three-man commission to "revise, simplify, arrange, and consolidate all statutes of the. United States." ${ }^{26}$ In light of the commissioners' duties, ${ }^{27}$ the fate of section 1 of the 1866 Civil Rights Act is readily discovered. The first part, extending citizenship to the freedmen, had already been superseded by section 1 of the fourteenth amendment..8 Since the portion dealing with the right to buy and sell property had no counterpart in any later law, R.S. 1978 was taken from the 1866 act. The remainder of section 1,29 however, was very similar to section 16 of the 1870 act. $^{30}$

22 R.S. 1977, 1978 (1870).

2316 Stat. 140, 144 (1870).

24 Cong. Globe 1679-81. The bill was subsequently enacted on April 9, 1866, over the President's veto. Cong. Grobe 1861.

25 The fourteenth amendment was not officially adopted until more than two years after the passage of the 1866 Civil Rights Act.

A different justification for $\S 18$ is suggested in Kohl, supra note 10, at 295-9. However, the author reaches the same conclusion that the 1870 act was not intended to restrict the scope of the 1866 act.

2614 Stat. 74 (1866).

27 [T] which, from similarity of subject, ought to be brought together, omitting redundant or obsolete enactments, and making such alterations as may be necessary to reconcile the contradictions, supply the omissions, and amend the imperfections of the original text.

14 Stat. 74.

28 All persons born or naturalized in the United States, and subject to the jurisdiction thereof are citizens of the United States and of the State wherein they reside. ..

20 The truncated version of $\$ 1$ would read as follows:

[A]11 ... citizens of the United States ... . of every race and color, without regard to any previous condition of slavery or involuntary servitude, except as a punishment for crime whereof the party shall have been duly convicted, shall have the same right, in every State and Territory in the United States, to make and enforce contracts, to sue, be parties and give evidence.... and to full and 
Where the statutes are different, the language of the 1870 act is broader. It applies to "all persons within the jurisdiction of the United States," not just to citizens. It assures that all persons shall be subject to like "taxes, licenses, and exactions of every kind," as well as like "punishment, pains, and penalties." The only wording that is in the earlier bill but omitted from the later bill is the specific reference to a "previous condition of slavery or involuntary servitude" which emphasized the thirteenth amendment foundation of the 1866 act but was superfluous. Thus, section 1981 retains at least the scope of the 1866 act as that scope is discoverable from the act's legislative history.

\section{Effect of the Givil Rights Act of 1964}

Beginning in 1943 a number of bills were proposed to enact federal fair employment practice legislation. ${ }^{31}$ Success was finally achieved in 1964 with the passage of the 1964 Civil Rights Act, Title VII of which created the Equal Employment Opportunity Commission (EEOC) ${ }^{32}$ and erected a complex administrative structure for processing complaints and conciliating disputes. Therefore, it is necessary to consider whether passage of the 1964 act has preempted all or part of the employment discrimination coverage of section 1981.

\section{A. The Implied Repeal Issue}

In Jones $v$. Mayer the court refers to the statement in Posadas $v$. National City Bank that "[t]he cardinal rule is that repeals by implication are not favored." 33 But the Posadas case goes on to indicate the flexibility of this "cardinal rule":

Where there are two acts upon the same subject, effect should be given to both if possible. . . [W] [Were provisions in the

equal benefit of all laws and proceedings for the security of person and property, as is enjoyed by white citizens, and shall be subject to like punishment, pains, and penalties, and to none other, any law, statute, ordinance, regulation, or custom to the contrary notwithstanding.

30 The relevant portion of which reads:

[A]ll persons within the jurisdiction of the United States shall have the same right in every State and Territory in the United States to make and enforce contracts, to sue, be parties, give evidence, and to the full and equal benefit of all laws and proceedings for the security of person and property as is enjoyed by white citizens, and shall be subject to like punishment, pains, penalties, taxes, licenses, and exactions of every kind, and none other, any law, statute, ordinance, regulation, or custom to the contrary notwithstanding.

16 Stat. 140, 144.

31 For a brief history of these proposals, see EEOC, Legistatrve History of Trtles VII AND XI of CiviL RIGHTS ACT OF 1964, at 7-9 (1968).

3242 U.S.C. $\$ 2000 \mathrm{e}-4$ (1964).

33296 U.S. 497, 503 (1936), quoted at 392 U.S. 437. 
two acts are in irreconcilable conflict, the later act to the extent of the conflict constitutes an implied repeal of the earlier one .... ${ }^{34}$

This rule leaves the court considerable leeway in determining whether and to what extent conflicts are irreconcilable.

In the case at hand the conflicts are fairly clear and may be grouped in three general categories-classes of persons covered by the act, availability of immediate access to the courts, and substantive nature of the acts prohibited. Section 1981 would appear to apply to all employers; Title VII has a number of important exclusions. Title VII poses several barriers between the plaintiff and the courts, while the 1866 act would allow direct access. The substantive scope of section 1981 remains largely undefined; Title VII specifically declares certain practices not to be forbidden by the act.

The extent to which the two statutes are irreconcilable is much harder to determine. The words of the statutes offer little assistance, and specific congressional intent was nonexistent in 1964, since section 1981 lay dormant until the Jones case. Nevertheless, the courts must somehow resolve the preemption issue when the conflict reaches them. To determine how their wide discretion under the Posadas rule should be exercised, they must find an answer to the question, "What would the intention of Congress have been if it had known of the possible availability of the 1866 act?'35 To answer that question the conflicting Title VII provisions must be examined in light of the reasons for their existence. To the extent that Congress actually intended certain discriminatory acts to be allowed, the provisions support the argument for implied repeal. Where no such intention is shown, the apparent conflicts are not irreconcilable and no support is provided for the position that Title VII effected a partial implied repeal of section 1981. The specific concern of this comment is not to establish whether particular Title VII provisions might be applied to

34296 U.S. at 503. The case also states a second rule where "the later act covers the whole subject of the earlier one," which is not relevant here since $\$ 1981$ covers other contracts as well as rights other than the right to contract.

35 Denning, L.J., expressed the court's duty in Seaford Court Estates v. Asher:

A judge, believing himself to be fettered by the supposed rule that he must look to the language and nothing else, laments that the draftsmen have not provided for this or that, or have been guilty of some or other ambiguity. It would certainly save the judges trouble if Acts of Parliament were drafted with divine prescience and perfect clarity. In the absence of it, when a defect appears a judge cannot simply fold his hands and blame the draftsman. He must set to work on the constructive task of finding the intention of Parliament .... A judge should ask himself the question: If the makers of the act had themselves come across this ruck in the texture of it, how would they have straightened it out? He must then do as they would have done, ...

[1949] 2 K.B. 481, 499. 
section 1981, but to deal with the threshold problem whether Title VII has totally repealed the employment discrimination coverage of section 1981.

In attempting to determine what Congress would have done if the availability of section 1981 had been known, the legislative history of the 1964 Civil Rights Act assumes great importance. The floor debates must be given much more weight than is usual in attempting to assess congressional intent, since there is no Senate report on H.R. 7152 which became the Givil Rights Act of 1964. Fearing that the bill would not return to the floor if referred to the Senate Judiciary Committee, the bill's supporters succeeded in bringing it directly to the floor without the benefit of committee consideration. ${ }^{36}$ While a filibuster began on the floor, a compromise bill was drafted by Senators Mansfield, Dirksen, Humphrey, and Kuchel, with the assistance of other Senators and Justice Department officials. ${ }^{37}$ Thus, the statements of the bill's supporters on the floor constitute the only record of what the bill was intended to accomplish. While there was a committee report on H.R. 7152 in the House, ${ }^{38}$ the bill also received considerable discussion on the floor of the House where a number of amendments were proposed, debated, and voted on..$^{39}$

Complexity in interpretation of the legislative history is added by the existence of Senate Rule XXII which requires a two-thirds vote to end debate and has long stood as a major obstacle to civil rights legislation. ${ }^{40}$ In construing a statute, courts generally refuse to examine the

36 The debate on the motion to refer the bill to committee is contained in 110 Cong. REc. 6417-27, 6428-38, and 6441-55 (1964).

37 See 110 CoNG. REc. 11935-6 (1964) (comments of Senator Dirksen on submission of the Dirksen-Mansfield bill).

38 H.R. REP. No. 914, 88th Cong., Ist Sess. (1963).

39 There are also three sets of hearings related to Title VII. The actual hearings on H.R. 7152 are Hearings Before Subcommittee No. 5 of the House Committee on the Judiciary, 88th Cong., Ist Sess., Ser. 4, pts. 1-4 (1963). The version of Title VII which was reported to the House was essentially the text of H.R. 405, then pending before the House Rules Committee, which the Judiciary Committee had substituted for the much weaker Title VII provided in the original version of H.R. 7152. Likewise, the Senate Committee on Labor and Public Welfare had approved a separate bill on employment discrimination, S. 1937, which was pending on the Senate calendar at the time that the Senate began consideration of H.R. 7152. Thus, the hearings and committee reports on H.R. 405 and S. 1937 form an important part of the background to Title VII.

40 The problem is well-illustrated by Senator Javits' remarks on the passage of the 1957 and 1960 civil rights acts:

[S]omehow or other that legislation was not written by the 71 Senators who were in favor of the bill, but what was written in it was very heavily conditioned by what the minority-those who voted against it-thought it ought to contain.

110 Cong. Rec. 3066 (1964). See also 110 Cong. REc. 12593-4 (1964) (remarks of Senator Clark).

The importance of the cloture vote on H.R. 7152 is evidenced by the fact that every 
legislative mechanics and political compromises which underlie it. The theory is that the courts look to "congressional intent" to explain what was meant by particular words or phrases, not to determine what the majority hoped to accomplish. In the case at hand, however, the issue is what the words of the statute probably would have been if Congress had assumed the availability of employment discrimination suits under section 1981.41 Since the search is to discover the reasons for including various provisions in Title VII, compromise necessitated by the cloture problem assumes the same significance as any other reason that can be found for the existence of a given provision.

\section{B. Title VII Exemptions}

The most apparent conflict between section 1981 and Title VII is the difference in the number of persons covered. While the coverage of the 1866 act would seem to extend to all employees, Title VII contains a number of exclusions from the definition of "employer" which leave 92 per cent of the employers and 60 per cent of the employees outside its coverage. ${ }^{42}$ The analysis below will attempt to determine the reasons for these exemptions and the implications of the exemptions for partial repeal of section 1981 .

1. Interstate commerce. Title VII covers only employers engaged in interstate commerce. ${ }^{43}$ Since the 1964 act was passed prior to recent Supreme Court decisions expanding the scope of the fourteenth amendment $^{44}$ and reviving the thirteenth amendment, ${ }^{45}$ the only constitutional basis advanced for Title VII during the debate was the commerce clause. ${ }^{46}$

2. Twenty-five or more employees. Only employers of 25 or more employees are subject to Title VII.47 The first suggested reason for this limitation is found in the separate views of Representatives Poff and Cramer accompanying the committee report on H.R. 7152. ${ }^{48}$ They

Senator was present to vote on the issue, including Senator Engle, who had to be brought to the floor in a wheelchair. Cloture was effected by a vote of 71 to $29-\mathrm{a}$ shift of five votes would have meant the defeat of the bill. 110 CoNG. REc. 13327 (1964).

41 See text at note 35 supra.

42 These figures are taken from Department of Labor statistics based on Social Security returns. See 110 CoNG. REC. 13090 (1964).

4342 U.S.C. $\$ 2000 \mathrm{e}(\mathrm{b})$ (1964).

44 See note 9 supra.

45 Jones v. Mayer, supra; see quote in text at note 10 supra.

46 See, e.g., 110 CoNG. REc. 1528 (1964) (memorandum submitted by Representative Celler), 6548 (statement by Senator Humphrey), 7209 (Department of Justice memorandum), 7210 (Department of Labor memorandum), 8453 (memorandum of Association of the Bar of the City of New York), 12617 (statement by Senator Muskie).

4742 U.S.C. $\$ 2000 \mathrm{e}(\mathrm{b})$ (1964).

48 H.R. REP. No. 914, pt. 1 at 108. This line of reasoning was also discussed by Representative Poff during the floor debates. 110 CoNG. REc. 2576 (1964). 
suggest that a firm employing fewer than this minimal number of employees is too small to be "affecting" interstate commerce. Senator Cotton presented several additional reasons for requiring a minimum number: the federal government would have difficulty enforcing the act if it had to investigate all firms; the federal government should not intrude on the intimate employer-employee relationships in small firms; and small businessmen should not have to endure still more arbitrary government harassment. ${ }^{49}$ Senator Javits then asserted that 25 was settled on as a part of the compromise to effect cloture. ${ }^{50}$

Senator Javits appears correct in identifying cloture as the reason for settling on a cutoff of 25 , since many Senators favored substituting a smaller number. A Senate committee had approved S. 1937, ${ }^{\text {,1 }}$ which would have applied to employers of eight or more, by a 12-3 margin. An amendment raising the Title VII limitation from 25 to 100 was defeated by a 63-34 margin. ${ }^{62}$ But this analysis fails to explain why all versions of Title VII contained some cutoff. Of the four reasons suggested above, two seem to merit consideration-concern for the personal nature of small businesses and concern with the difficulty and expense of federal enforcement.

That Congress was concerned with the close, personal atmosphere of small businesses is supported by examination of Title II of the 1964 Civil Rights Act and Title VIII of the 1968 Givil Rights Act. ${ }^{53}$ Title II, dealing with discrimination in public accommodations, not only

49110 CoNG. REC. 13085 (1964).

50110 CoNG. REc. 13090 (1964).

61 A comparative analysis of H.R. 7152 and S. 1937 is included in the record at 110 CONG. REC. 12596-8 (1964).

52110 Cong. REc. 13093 (1964). The discussion in the text of the compromise settlement on 25 as a cutoff does not consider the attitude of the House, which had to approve any amendments to the House version. The simple reason is that the issue was never raised there and no vote or debate on the specific issue exists. The closest analogy was an amendment which was adopted delaying full coverage of the act for an additional year. See 42 U.S.C. $\$ 2000$ (b), (c) (1964). None of the debate on that amendment sheds any light on the issue at hand. See 110 CoNG. REc. 2716-8 (1964).

If the Senate had lowered the limitation, it is unlikely that the House would have objected. On return to the House, H.R. 7152 was approved in whole by a vote of 289-126 rather than being referred to a Conference Committee to work out differences with the Senate version. See 110 CoNG. REc. 15897 (1964). Since whatever sentiment existed in the House was not strong enough to lead anyone to propose an amendment altering the cutoff number, it seems highly unlikely that a Senate amendment would have evoked such strong feeling as to shift the 82 votes necessary to send the bill into conference.

There is also some evidence that the members of the House would not have been opposed to lowering the number from 25 in any event. Two years after the passage of the 1964 Civil Rights Act the House passed a proposed Equal Employment Opportunity Act of 1965 which was never acted upon in the Senate. Among other changes, the bill would have lowered the 25 employee cutoff to eight. Passage was by a vote of 300 to 93 . 112 Cong. Rec. 9153 (1966).

53 42 U.C.S.A. $\$ \S 3601-19$ (1969 Supp.). 
excludes private clubs from its coverage ${ }^{54}$ but also inns, hotels, and motels with five or fewer rooms for rent, of which the proprietor is a resident.55 Title VIII of the 1968 act deals with discrimination in the sale or rental of housing. Exempted from the act's coverage are

... rooms or units in dwellings containing living quarters occupied or intended to be occupied by no more than four families living independently of each other, if the owner actually maintains and occupies one of such living quarters as his residence. ${ }^{56}$

The inclusion of such a provision had been hotly debated both in 1968 and in 1966 when another fair housing bill had been considered. ${ }^{67}$ This reflects a continuing congressional concern that individuals be free to select their own intimate associates.

The difficulty of federal enforcement is demonstrated by 1964 Social Security returns which listed 3.3 million employers and 73 million employees in the country. ${ }^{58}$ Inclusion of all employers would have required appropriation of far more funds for the program, and might still have swamped the new, untried administrative structure. ${ }^{59}$ It seems to be this problem which was the primary reason for imposing the 25 employee limitation. The House report on H.R. 7152 recognized that the bill would only be able to deal with the most serious types of discrimination.60 Moreover, Senator Clark, one of the Senate floor managers for Title VII, gave this reply to opponents who suggested that Title VII was internally discriminatory because of its exclusions:

With respect to the elimination of employers of less than 25 persons, both administrative difficulties and financial limitations make it unrealistic to attempt, in this first Federal legislative venture in the area of fair employment, to cover the whole field of discrimination. Experience in states having FEP laws demonstrates that if discrimination is barred by large-

54 42 U.S.C. $\S 2000 \mathrm{a}(\mathrm{e})(1964)$.

5542 U.S.C. $\$ 2000 \mathrm{a}(\mathrm{b})(1\rangle(1964)$.

5642 U.S.C.A. \& 3603(b)(2) (1969 Supp.).

57 H.R. 14765, a proposed Civil Rights Act of 1966, was approved by the House, but died in the Senate.

58110 Cong. Rec. 13090 (1964).

59 Despite limiting the coverage of Title VII, Congress still underestimated the extent of the problem. The EEOC was budgeted to handle 2000 complaints in its first year of operation. It received 8,854. 113 ConG. Rrc. 11510 (1967). Congress had also anticipated that complaints could be disposed of within 30 days or 60 days at the most. See 42 U.S.G. $\S 2000 \mathrm{e}-5(\mathrm{e})$ (1964). In fact, complainants typically have to wait about eighteen months for disposition of their cases.

60 H.R. REP. No. 914, pt. 1 at 18. 
and middle-sized employers . . . the back of the evil can be broken. ${ }^{61}$

3. United States Government. The definition of employer excludes the United States and its wholly owned corporations. ${ }^{62}$ This provision was included in the belief that existing law was sufficient to deal with discrimination by the federal government. ${ }^{63}$ The civil service regulations prohibit discrimination in the competitive service. ${ }^{64}$ Moreover, under the authority of Executive Order 10925, ${ }^{65}$ the President's Committee on Equal Employment Opportunity had undertaken an affirmative action program in government employment and implemented a complaint procedure to investigate discrimination charges by government employees. ${ }^{60}$

4. Indian tribes. Senator Mundt explained his amendment to exclude Indian tribes from the definition of employer ${ }^{67}$ as necessary because "Indian tribes, in many parts of the country, are virtually political subdivisions of the Government." 68 Senator Humphrey assented to the amendment on behalf of the supporters of Title VII, noting that, "[a]ny economic activity on the part of the Indian tribes must have the approval of the Secretary of the Interior." 69 The real end sought was freedom to discriminate in favor of Indians, not freedom to discriminate among other applicants for employment, as is evidenced by section 703(i) which allows businesses on or near Indian reservations to adopt a hiring policy which gives preference to Indians. ${ }^{70}$

5. State governments. Both state and local governments are excluded from the definition of "employer."71 Apparently this exclusion was appended in deference to the federal structure of the nation. ${ }^{72}$ Congress must also have been aware that discrimination by such agencies was already prohibited by the fourteenth amendment.

6. Private membership clubs. The exclusion of private mem-

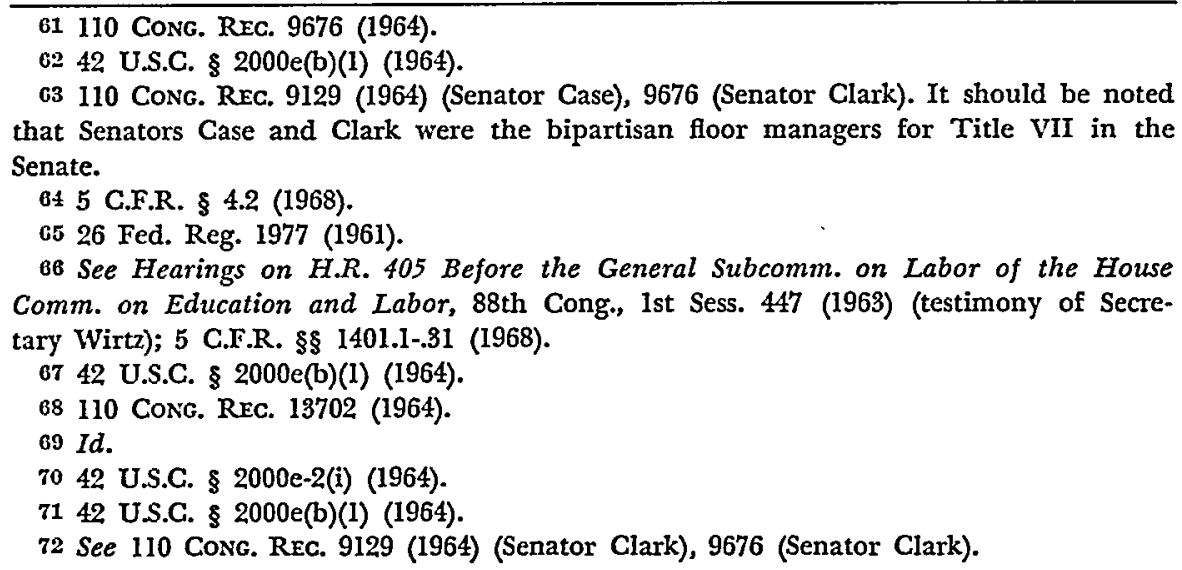


bership clubs from Title VII ${ }^{73}$ appears to reflect the concern discussed above ${ }^{74}$ that individuals be free to select their own personal associates. Thus, the exclusion of private membership clubs appears in the public accommodations title of the $1964 \mathrm{act}^{75}$ as well as in Title VII. The rationale does not apply to employment since a club employee's relationship is more similar to that of an employee of a public accommodation than to that of a club member. ${ }^{76}$ Nevertheless, the congressional intent clearly appears to sanction such discrimination.

7. Educational institutions. Immunity is also granted to educational institutions "with respect to the employment of individuals to perform work connected with the educational activities of such institution." 77 The reason for this exemption seems to be a simple policy of not imposing federal regulation on educational activities. ${ }^{78}$ Thus, the exclusion applies only to "educational activities" and does not exempt such jobs as campus gardener, superintendent, policeman, or departmental secretary. ${ }^{79}$

8. Title VII exemptions: implications for repeal. The issue is whether the reasons motivating these seven exemptions support the position that Title VII effected a partial implied repeal of section $1981 . .^{\circ}$ The existence of the federal government exemption can scarcely be construed to support an argument for implied repeal of any prior statute since its inclusion was justified by the protection afforded by existing laws. While the state and local governments exemption seems to be based on an intention not to impose federal regulation on those agencies as employers, no support for implied repeal can

7342 U.S.C. § $2000 \mathrm{e}(\mathrm{b})(2)(1964)$.

74 Text at notes $53-56$ supra.

7542 U.S.C. $\S 2000 \mathrm{a}$ (e) (1964).

76 The exclusion of private clubs seems highly questionable when it is remembered that Title VII affects employment, not membership rights. While club members can plausibly claim a special interest in their choice of associates, their claim to discriminate in the hiring of waiters is hardly entitled to the same respect.

SOVERN, Legal Restraints on RACLAL Discrimination IN EMPLoyment 66 (1966) (emphasis in text).

7742 U.S.C. $\$ 2000 \mathrm{e}-1$ (1964).

78 See SOVERN, supra note 76 , at 68 . The educational institution exemption was one of the changes made by the Dirksen-Mansfield substitute and no issue was raised on the floor about the change.

79 EEOG General Counsel Opinion Letter, March 3, 1966, CCH EMPLOYMENT PRActrce Guine I 17,252.025, at 7362.

80 Two additional exemptions pose no conflict with section 1981. The exemption for aliens outside any state is irrelevant because such aliens would not be "persons within the jurisdiction of the United States" and are already excluded from section 1981. See 42 U.S.C. § 2000e-1. The provision allowing religious organizations to discriminate on the basis of religion where the job is related to the organization's religious activities is irrelevant because section 1981 deals only with discrimination on the basis of race. See 42 U.S.C. \$ 2000e-1 (1964). 
be drawn from that. Since Congress did not repeal 42 U.S.G. $§ 1983$, a very active and viable section providing redress for persons deprived of their fourteenth amendment equal protection rights, no intent to repeal existing laws can be drawn from that exemption.

Since the interstate commerce requirement was included solely to insure the constitutionality of Title VII, it has no implications for repeal of section 1981. To the extent that the exemption of Indian tribes is justified by federal supervision of them, it lends no more support to the implied repeal argument than does the federal government exemption itself. To the extent that it was intended to allow discrimination in favor of Indians, it lends slight support-only slight because it shows congressional intent to allow discrimination in favor of Indians over Negroes and whites, but not in favor of whites over Negroes. Further, this provision may not even conflict with section 1981 since it is at least arguable that the 1866 act also excludes Indian tribes. $^{81}$

Though Congress apparently intended to allow private membership clubs to discriminate, the support provided by this exemption is not strong. Since the provision is not supported by its rationale, it is possible that fuller consideration might have resulted in its deletion. It appears from the care taken to exclude private clubs from Title II of the 1964 act $^{82}$ and the lack of debate on the exemption in Title VII that the policy of exempting private clubs from civil rights legislation was simply followed without being analyzed. Similarly, the educational institutions exemption seems to represent a value judgment that discrimination is a lesser evil than federal intervention into educational activities. That judgment is no better founded in reason than the

81 The principle in Elk v. Wilkins, 112 U.S. 94 (1884), has represented a consistent rule of statutory construction: "General acts of Congress [do] not apply to Indians, unless so expressed as to clearly manifest an intention to include them." Id. at 100. This rule has been modified somewhat by the Supreme Court's more recent statement that "it is now well settled ... that a general statute in terms applying to all persons includes Indians and their property interests." F.P.C. v. Tuscarora Indian Nation, 362 U.S. 99, 116 (1960). However, it is not clear that $\S 1981$ uses such all-inclusive language as to bring the Indian tribes within its coverage because of their peculiar status in our federal system.

§ 1981 applies, by its terms, "in every State and Territory." It has been clear at least since Justice Marshall's decision in Worcester v. State of Georgia, 31 U.S. (6 Pet.) 515 (1832), that the status of Indian tribes is as separate nations or entities having some degree of sovereignty. In the words of a Tenth Circuit decision, "Indian tribes are not states. They have a status higher than that of states. They are subordinate and dependent nations ...." Native American Church of North America v. Navajo Tribal Council, 272 F.2d 131, 134 (10th Cir. 1959). While it is clear that Indian reservations are part of the territory of the United States (Colliflower v. Garland, 342 F.2d 369 (9th Cir. 1965)), it is far from clear that they are "territories" for purposes of $\S 1981$.

8242 U.S.C. $\$ 2000 \mathrm{a}(\mathrm{e})$ (1964). For the congressional discussion of this subsection, see 110 CoNG. RFc. 6006-8, 9079-81 (1964). 
private club exemption, since "a law forbidding employment discrimination seems a most unlikely road to federal control of education." 83

This leaves only the 25 employee requirement for consideration. To the extent that Congress intended to allow discrimination rather than permit federal regulation to intrude into the personal atmosphere of small businesses, the provision lends support to the argument for implied repeal. But analysis has revealed the primary justification to be the problems of administrative enforcement. Therefore, the provision lends no support to the argument for implied repeal of section 1981 which requires no involvement by a federal agency. Indeed, the provision even supplies a positive argument against implied repeal. If parallel causes of action are available, the burden on the EEOC will be eased to the extent that plaintiffs choose to proceed under the 1866 act rather than Title VII. ${ }^{84}$.

That the specific cutoff of 25 was settled on as a compromise necessitated by Rule XXII also undercuts any argument that this exemption supports implied repeal. When the cloture problem is the primary reason for a provision, that provision lends no support to the argument for implied repeal because repeal, like enactment, is a positive legislative act which can take place only when the rules of the body are adhered to and the political obstacles are surmounted. Therefore, if section 1981 had been a viable provision in 1964, cloture as a political weapon would have been in the hands of the supporters of Title VII rather than its opponents. The compromises would have been quite different. This is not to say that all the Title VII exemptions may be ignored; it is only to say that where there is strong evidence that a given provision was accepted primarily to attain cloture the provision should not be regarded as lending support to the implied repeal argument.

\section{Title VII Procedural Prerequisites}

The second area of conflict between section 1981 and Title VII involves the availability of direct access to the courts. Title VII includes a number of procedural requirements which must be met before the plaintiff may take his case to court. While most of these are minor and irrelevant to the issue of implied repeal, two constitute more significant obstacles and are based on highly relevant policy considerations.

1. Deferral to state agencies. One of the major changes effected by

\footnotetext{
83 SOVERN, supra note 76 , at 68 .

84 This argument assumes some importance when consideration is given to the actual problem posed by the Commission's work load. See note 59 supra.
} 
the Senate compromise was to require that all complaints be referred to the state fair employment practice agencies prior to consideration by the EEOC. ${ }^{85}$ The basic policy expressed was "that States and localities be afforded every opportunity to resolve these difficult problems of racial justice by means of their own agencies and instrumentalities." the opportunity to utilize their "expertise and experience."8t

The real reason for the change appears to be the cloture problem. Under the House version of H.R. 7152, the state commissions would have had no involvement in the processing of charges filed with the EEOG unless they had entered into agreements with the Commission under section 708(b) of that bill. Thus, they would have been required to both meet EEOC standards of "effectively exercising" their power to eliminate discrimination, and enter into an agreement which presumably would have stipulated standards and operating procedures satisfactory to the Commission. It is apparent that this was only a token concession to state involvement, considering the extent to which the state agencies would have had to submit to EEOC oversight and supervision.

On April 21, 1964, Senator Dirksen, the acknowledged leader of the Republican Senators who could swing the cloture vote, had submitted a proposed amendment to Title VII. His amendment would have required deferral to state agencies for a period of 90 days and would have deleted the provision allowing agreements between the EEOC and state agencies. ${ }^{88}$ The Dirksen-Mansfield substitute struck a clear compromise between the House bill and the Dirksen amendment. Section $706(\mathrm{~b})^{89}$ imposes mandatory deferral, but for 60 days rather than 90 . Section $709(\mathrm{~b})^{30}$ retains the essence of the House bill, somewhat modified. That the cloture problem was the primary reason for adding the mandatory deferral provision seems beyond dispute.

2. Reliance on conciliation. One of the aims of the commission procedure was to provide informal means of settling complaints without resort to the courts. ${ }^{91}$ Thus, the EEOC is directed to attempt conciliation when it finds reasonable cause to believe that a charge is

\footnotetext{
8542 U.S.C. $\S 2000 \mathrm{e}-5(\mathrm{~b})$ (1964). See 110 CoNG. REG. 12723 (1964) (discussion by Senator Humphrey), 12595 (Senator Clark).

86 Senator Humphrey, 110 CoNg. Rec. 12724-5 (1964).

87 Senator Humphrey, 110 CoNG. REc. 12725 (1964).

88110 CoNG. REC. 8593 (1964).

8942 U.S.C. § $2000 \mathrm{e}-5(\mathrm{~b})$ (1964).

9042 U.S.C. $\$ 2000 \mathrm{e}-8(\mathrm{~b})(1964)$.

91 See 110 Cong. REc. 12617 (1964) (Senator Muskie), 6563 (Senator Kuchel), 6549 (Senator Humphrey).
} 
true, ${ }^{92}$ and complainants must allow the EEOG 60 days to investigate a charge and attempt conciliation before going to court. ${ }^{93}$

3. Procedural prerequisites: implications for repeal. The congressional intent that grievances be settled informally seems clear. But court interpretation of Title VII nullifies any apparent resulting support for implied repeal. Because of the backlog of cases and inherent delays in processing, the EEOG can rarely reach a cause or no-cause finding in sixty days, let alone attempt conciliation. ${ }^{94}$ Recognizing this problem, the courts allow suit to be brought after the lapse of sixty days even if no conciliation has been attempted. ${ }^{95}$ Moreover, access to the courts is not barred by the plaintiff's rejection of a proposed conciliation agreement. ${ }^{96}$ Since congressional emphasis on conciliation has been held insufficient to bar suit under Title VII, it should not be regarded as supporting implied repeal of section 1981.

It has been pointed out above that a compromise to effect cloture lends little or no support to the argument for implied repeal. ${ }^{97}$ Since the mandatory state deferral provision is clearly one of those necessitated by Rule XXII, it should not be relied on as support for implied repeal.

\section{Title VII Substantive Provisions}

Most of the substantive provisions of Title VII are irrelevant to the implied repeal issue-primarily because they are expressed in broad, sweeping terms whose limits are undefined. However, those provisions

9242 U.S.C. § 2000e-5(a) (1964).

9342 U.S.C. $\$ 2000 \mathrm{e}-5(\mathrm{e})(1964)$, as implemented by 29 C.F.R. $\S 1601.25 \mathrm{a}$ (a) (1968).

94 This problem is reflected in the Commission's regulations which have effected an automatic exercise in all cases of the Commission's option under 42 U.S.C. $\$ 2000 e-5$ (e) to extend the investigation and conciliation period from thirty days to sixty. 29 C.F.R. $\S 1601.25 \mathrm{a}(\mathrm{a})$ (1968).

95 A minority of district courts had held to the contrary, but the Circuit Courts of Appeals have uniformly upheld this rule. Miller v. International Paper Co., 408 F.2d 283 (5th Cir. 1969); Dent v. St. Louis-San Francisco R.R., 406 F.2d 399 (5th Cir. 1969); Johnson v. Seaboard Air Line R.R., 405 F.2d 645 (4th Cir. 1968), cert. denied sub nom. Pilot Freight Carriers v. Walker, 394 U.S. 918 (1969); Choate v. Caterpillar Tractor Co., 402 F.2d 357 (7th Gir. 1968). The case of Mickel v. South Carolina State Employment Service, 377 F.2d 239 (4th Cir.), cert. denied, 389 U.S. 877 (1967), is commonly cited to the contrary, but the actual issue there was whether the defendant had to be named at all in a charge filed with the EEOC before an action could be brought against him. To the extent that the case conflicts with the rule expressed in the text it is best regarded as overruled by Johnson v. Seaboard Air Line R.R., supra.

96 This is the only interpretation consistent with the purposes of the act and structure of the Commission. To hold otherwise would prevent effective protection of the individual rights guaranteed by the Act.

Cox v. United States Gypsum Co., 284 F. Supp. 74, 84 (N.D. Ind. 1968) aff'd 409 F.2d 289 (7th Cir. 1969); see EEOC General Counsel Opinion Letter, July 20, 1966, CCH EMPLOYment Practice Guide If 17,304.03.

97 See text after note 84 supra. 
declaring certain employment practices not unlawful support implied repeal to the extent that those practices might be prohibited by section $1981 . .^{88}$

Two of the validating provisions do not allow practices which would otherwise be violations of either Title VII or section 1981. An employer may fire or refuse to hire a person who does not have a security clearance required for a job. ${ }^{99}$ However, neither statute would otherwise make that unlawful unless the employer were shielding discrimination behind unnecessary security requirements. ${ }^{100}$ Bona fide seniority and merit systems are validated under Title VII, ${ }^{101}$ but a "bona fide" system is presumably a nondiscriminatory one by definition.

Under Title VII, businesses near Indian reservations are permitted to discriminate in favor of Indians. ${ }^{102}$ Since the employer's hiring policy must specifically favor Indians, the provision still appears to afford Negroes "the same right as whites" to make and enforce contracts.

The implications of two substantive provisions are rendered ambiguous by their legislative history. The first provision, allowing employers to utilize professionally developed ability tests which are not "designed, intended or used to discriminate because of race, color, religion, sex or national origin," 103 came into the law as a reaction to the hearing examiner's report in Myart $v$. Motorola, a case arising under the Illinois Fair Employment Practice Act. ${ }^{104}$ The hearing examiner in that case held that a standardized test violated the Illinois act because it was unfair to culturally deprived and disadvantaged groups. ${ }^{105}$ Whether the resulting provision in Title VII validated tests which otherwise would have been prohibited by either Title VII or section 1981 is doubtful since it still prohibits the use of such tests

98 Three substantive provisions are not considered in the text because they do not deal with discrimination on the basis of race and are irrelevant to section 1981. Those provisions allow bona fide occupational qualifications (42 U.S.C. § 2000e-2(e)(1) (1964)), religious discrimination by church-affliated schools (42 U.S.C. $\$ 2000 \mathrm{e}-2(\mathrm{e})(2)$ (1964)), and sex discrimination authorized by the Fair Labor Standards Act. (42 U.S.C. $\S 2000 \mathrm{e}-2(\mathrm{~h})$ (1964)). 3942 U.S.C. $\$ 2000 \mathrm{e}-2(\mathrm{~g})(1964)$.

100 See 110 Cong. Rec. 12723 (1964) (Senator Humphrey): "The provision thus adds no new substantive exemption, but merely makes express what would have been possible even without the amendment."

10142 U.S.C. $\$ 2000 \mathrm{e}-2(\mathrm{~h})(1964)$.

10242 U.S.C. \$ 2000e-2(i) (1964).

10342 U.S.C. $\$ 2000 \mathrm{e}-2(\mathrm{~h})$ (1964).

104 Congressional reaction to the Illinois decision was strong, and numerous references were made to the case throughout the long foor debate on the 1964 Civil Rights Act. The primary substantive debate was on an amendment proposed by Senator Tower stronger than the amendment eventually adopted. See 110 CoNG. REc. 13492-505 (1964).

105 The hearing examiner's decision is printed at 110 CoNG. REc. 5662-4 (1964). 
if "designed, intended or used to discriminate."106 This position is supported by the Senate's rejection of Senator Tower's first amendment to allow professionally developed ability tests, ${ }^{107}$ followed by unanimous acceptance of the present provision with full approval of both the Justice Department and Senate leadership. ${ }^{108}$

The other provision subject to debate excludes from the term "unlawful employment practice" actions taken with respect to members of the Communist Party or other organizations required to register with the Subversive Activities Control Board. ${ }^{109}$ The text of the provision and statements by its author indicate that it applies regardless of the grounds of discrimination alleged. ${ }^{110}$ However, Representative Celler, the floor manager for the bill, and Representative Roosevelt, author of the bill which became Title VII, did not oppose the amendment, but asserted in a prepared memorandum that the amendment effected no substantive change because Title VII was totally unconcerned with political or subversive activities. ${ }^{111}$ Senators Case and Clark, the bipartisan floor managers for Title VII in the Senate, submitted an interpretative memorandum on Title VII which also gave this provision the Celler-Roosevelt construction. ${ }^{112}$

For the purpose of determining the relevance of this provision to implied repeal, it is best given the construction of the Senate and House managers of Title VII-as allowing discrimination against communists only because they are communists. Not only is it probable that many supporters of Title VII acted in reliance on the leadership interpretation, but the provision, if literally interpreted, is of very doubtful constitutionality. ${ }^{113}$ Therefore, courts are likely to give the provision the more limited construction to preserve its constitutionality.

\section{E. Title VII and Preexisting Law}

Several active, viable laws dealing with aspects of employment discrimination existed prior to enactment of Title VII. The relation of

106 It must be kept in mind that the plaintiff in a Title VII action always carries the burden of proving that the defendant has "intentionally engaged in or is intentionally engaging in" a forbidden practice in order to win his case. 42 U.S.C. $\$ 2000 \mathrm{e}-5(\mathrm{~g})(1964)$. 107110 CoNG. REC. 13505 (1964).

108110 Cong. REc. 13724 (1964).

10942 U.S.C. § 2000e-2(f) (1964).

110110 Cong. REc. 2719 (1964) (Representative Colmer).

111110 CoNg. REc. 2719 (1964).

112110 CoNG. REc. 7213 (1964).

113 A limited selection of authorities on this issue is presented in a footnote in Report on Proposed Federal Legislation Relating to Equal Employment Opportunity, 19 RECORD OF THE ASS'N OF THE BAR OF THE CITY OF NEW YORK 230, 236 (1964). The provision in question falls squarely within the prohibition of the unconstitutional conditions doctrine. See Comment, Another Look at Unconstitutional Conditions, 117 U. PA. L. REv. 144 (1968). 
Title VII to these laws constitutes valuable evidence as to what the intended relation of Title VII to section 1981 would have been. In this regard, it is important that Senator Tower's amendment to exclude any agency but the EEOG from dealing with practices covered by Title VII was rejected by more than a 2-1 margin. ${ }^{114}$ That Congress generally intended to adhere to existing anti-discrimination laws rather than to repeal them is supported by the decision to exempt the federal government because of the existence of adequate prior law.115 Rather than add to the burden of the EEOG, Congress chose to direct the President to utilize his existing authority to insure equal employment opportunity for federal employees.110

Senator Hill asserted, early in the debates, that the House version of H.R. 7152 "would make it possible for labor unions to be denied their representation rights under the National Labor Relations Act and the Railway Labor Act."117 A rebuttal, drafted by the Department of Justice at the request of Senator Clark, took the position that Title VII would have no effect on union representation rights, stating in part:

Of course, title VII is not intended to and does not deny to any individual, rights and remedies which he may pursue under other Federal and State statutes. If a given action should violate both title VII and the National Labor Relations Act, the National Labor Relations Board would not be deprived of jurisdiction. ${ }^{118}$

The limited case law supports Senator Clark rather than Senator Hill. Both the Fifth Circuit ${ }^{119}$ and the District of Columbia Circuit ${ }^{120}$ have stated that Title VII has not preempted any jurisdiction of the NLRB. Two district courts have even held that a Title VII action may not be brought in a case falling under the RLA or NLRA, ${ }^{121}$ though this position is unlikely to be sustained on appeal.

114 See 110 CoNG. REc. 13650-2 (1964).

115 See note 68 supra.

11042 U.S.C. \& $2000 \mathrm{e}(\mathrm{b})$. In accordance with this directive President Johnson issued Executive Order 11246 which charges the Civil Service Commission with responsibility for preventing discrimination in federal employment and directs the head of each executive department and agency to establish a program of equal employment opportunity. See 30 Fed. Reg. 12319 (1965).

117110 Cong. Rec. 486 (1964).

118110 Cong. REC. 7207 (1964).

119 Local 12, United Rubber Workers v. NLRB, 368 F.2d 12, 24 (5th Cir. 1966) (dictum).

120 United Packinghouse, Food and Allied Workers International Union v. NLRB, No. 21,627 (D.C. Cir., Feb. 7, 1969).

121 Norman v. Missouri Pacific R.R., 58 CCH Lab. Cas. I 9144 (E.D. Ark. 1968) (pending appeal); Freese v. John Morrell \& Co., $60 \mathrm{CCH}$ Lab. Cas. ๆ 9231 (S.D. Iowa 1966). Contra, Sokolowski v. Swift \& Co., 286 F. Supp. 775 (D. Minn. 1968). 


\section{F. Implied Repeal: Summary}

Analysis of the Title VII limitations has revealed little evidence to support preemption of section 1981. The reasons underlying the Title VII provisions have shown most of the conflicts to be reconcilable. Of the seven Title VII exemptions, only those for educational activities and private clubs appear to evidence an intent to allow discrimination prohibited by section 1981. The procedural prerequisites, as construed by the courts, present no real conflict. Of the five substantive provisions posing potential conflict, only the communist exclusion presents a real conflict, and only then if applied literally. The relation of Title VII to preexisting law suggests intent to preserve rather than repeal prior law. The discoverable legislative intent does not support an implied repeal of section 1981.

Since the only cases relevant to the question whether employment discrimination suits may presently be brought under section 1981 are Jones $v$. Mayer and cases subsequently decided, the case law is meager and inconclusive. The Jones case itself supports the position that no implied repeal was effected by stating that enactment of the 1968 Civil Rights Act had no effect on section 1982.122. While this gives an indication of how the Court is likely to deal with the question, it certainly does not place the issue beyond debate. In the first place, there was no issue of preemption on the facts of the case since the cause of action arose nearly three years before passage of the 1968 act.

The relationship of the 1968 act to section 1982 may also be distinguished from the relationship of the 1964 act to section 1981. Since the Jones case entered the courts before consideration of the 1968 act began, the possible availabilty of a prior statute was pointed out to the Senate subcommittee holding hearings on fair housing legislation ${ }^{123}$ and was discussed during debate on the 1968 act. ${ }^{124}$ Thus, the silence of Congress in 1968 may more readily be interpreted as intent not to repeal, since the 88th Congress had no hint that section 1981 might be available. The second ground of distinction is that Title VIII of the 1968 act, unlike Title VII of the 1964 act, provides direct access to the courts. ${ }^{125}$ Thus, the old statute does not have the same appearance of thwarting the intention of Congress.

The few cases decided by the district courts since the Jones deci-

122392 U.S. at $416-7$.

123 Hearings Before the Subcomm. on Housing and Urban Affairs of the Senate Comm. on Banking and Currency, 90th Cong., 1st Sess. 229-30 (1967).

124 E.g., 114 CoNG. REc. H2806-7 (April 10, 1968).

12542 U.S.C.A. § 3612 (a) (1969 Supp.). On the other hand, this section specifically provides for continuances by the court for the purpose of allowing conciliation efforts to proceed. The differences between the two acts may be more apparent than real. 
sion are of less assistance than Jones itself. Dobbins $v$. Local 212, $I B E W,{ }^{126}$ the only case stating that a cause of action is available under section 1981, was also properly filed under Title VII; the issue of implied repeal was not considered. Colbert $v$. H-K Corporation, ${ }^{127}$ Kendrick v. American Bakery Company, ${ }^{128}$ and Norman v. Missouri Pacific Railroad ${ }^{129}$ all state simply that actions under section 1981 must allege some "color of state law"; none gives any consideration to the Jones case. In Culpepper v. Reynolds Metals section 1981 was given more careful consideration in a supplemental order after being brushed over very lightly in the initial decision. ${ }^{130}$ Although the court gave passing mention to Jones $v$. Mayer, the judge decided that the trial courts needed direction from above before taking such a step and the prior ruling was affirmed.131

Since the courts have considerable leeway in taking judicial notice of commonly known facts, there is a final point to be made about the background of the 1964 Civil Rights Act. Two external forces gave impetus to H.R. 7152. One was the assassination of President Kennedy in November of 1963.132 The second was the growing threat of riots in the streets as Negro impatience with racial inequality continued to grow. ${ }^{133}$ It is difficult to conceive of Congress repealing existing civil rights legislation in the spring of 1964. The courts are little justified in doing so now on the premise that section 1981 is a statute Congress did not know it could repeal in 1964.

\section{The Effects of Section 1981}

One major question remains to be answered in order to determine what position should be taken on the availability today of employment discrimination suits under 42 U.S.C. $\$ 1981$ : What will be the effects of allowing such suits to be brought under section 1981 ? That question has two distinctly different aspects; both require careful consideration.

126292 F. Supp. 413 (S.D. Ohio 1968).

127295 F. Supp. 1091 (N.D. Ga. 1968).

12859 CCH Lab. Cas. If 9146 (N.D. Ga. 1968).

12958 CCH Lab. Cas. I 9144 (E.D. Ark. 1968) (pending appeal).

130296 F. Supp. 1232 (N.D. Ga. 1969).

131296 F. Supp. at 1243 .

132 First, no memorial oration or eulogy could more eloquently honor President

Kennedy's memory than the earliest possible passage of the civil rights bill for

which he fought so long.

Address of President Johnson to joint session of Congress, November 27, 1963. 109 Cong. REC. 22839 (1963).

133 See, e.g., Hearings on H.R. 405, supra note 66, at 148, 232-3; 110 CoNG. REc. 1521. 1529, 1606, 1627-8, 12823 (1964). 


\section{A. Effects on Individual Plaintiffs}

The issue of preemption arises in a policy context unrelated to congressional intent. The courts are unlikely to resurrect another long dormant statute if there is no need to do so. Now that Title VII has been enacted, is there still a role to be played by section 1981?

In the first place, to those Negroes who are excluded from the coverage of Title VII, section 1981 represents their only access to the courts. The 25 employee cutoff alone exempts 13 million jobs from the coverage of Title VII. ${ }^{134}$ The number of suits brought by persons excluded from Title VII will probably be small. Only the most flagrant cases are likely ever to be taken to a lawyer since low income Negroes do not seek assistance from lawyers as often as middle class whites. Many of these cases will be screened out because attorney's fees are likely to be high in relation to the benefit sought for the plaintiff. Nevertheless, it is important that section 1981 be available to those persons who merit redress but happen to fall outside the scope of Title VII.

The primary use of section 1981 will be as a supplement to Title VII. Proceeding under the 1964 act has advantages ${ }^{135}$ which are likely to cause a much higher percentage of potential cases to be brought to the EEOC than will be taken to lawyers by persons excluded from Title VII. The 1964 act includes a number of procedural requirements, however, which can be fatal traps for the unwary. For example, the filing deadline under Title VII is only 90 days in many cases. ${ }^{136}$ "Since the [1866] Civil Rights Act itself contains no limitation period, the courts will look to the most analogous statute of limitations of the state where the cause of action arose."137 The longer statute of limitations would prevent plaintiffs from losing their cases because they did not immediately discover the discriminatory nature of an act or postponed filing a charge until angered by a later act not a violation of Title VII. Whether the party's failure to discover the discriminatory nature of an act or his pursuit of alternative remedies such as union grievance procedures will delay the running of the 90 day period is unsettled, ${ }^{138}$ but it seems more

134 Hearings on H.R. 8998 and H.R. 8999 before the General Subcomm. on Labor of the House Comm. on Education and Labor, 89th Cong., Ist Sess. 108 (1965) (testimony of the Chairman of the Equal Employment Opportunity Commission).

135 See text at notes 144-8 infra.

13642 U.S.C. $\$ 2000$ e.5(d) (1964).

137 Mulligan v. Schlachter, 389 F.2d 231, 233 (6th Cir. 1968).

138 Compare Antonopulos v. Aerojet-General Corp., 295 F. Supp. 1390, 1395 (E.D. Calif. 
likely that the statute will be literally construed to require filing within 90 days of the alleged unlawful act.

The 1866 act will also be relied on extensively by plaintiffs who fail to join all relevant parties in the charge filed with the EEOC. The courts have consistently refused to allow joinder of a defendant at trial if he was not named in the initial charge. ${ }^{139}$ This may only require the plaintiff to suspend legal action until a new charge has been processed, but it may result in the loss of his case against the omitted party if the violation was not a continuing practice and the 90 day filing period has expired. If the omitted defendant is held to be an indispensable party ${ }^{140}$ the plaintiff may lose his cause of action as to everyone. Section 1981, with its longer statute of limitations, avoids all of these problems by supplying an independent cause of action against the omitted party.

\section{B. Effects on Title VII}

The second important question is whether direct access to the courts under section 1981 would frustrate congressional intent by allowing plaintiffs to avoid the complex Title VII structure. Although this fear has been expressed by the courts in ruling that the EEOC can not be bypassed under Title VII,141 it seems totally unfounded for several reasons.

Past experience in the states has shown the importance of providing an agency to carry fair employment laws into effect. The first state statutes provided only criminal sanctions or a civil cause of action and were ineffectual until state fair employment practice commissions were created to assist with enforcement. ${ }^{142}$ The provision in

1968), with Culpepper v. Reynolds Metals, 296 F. Supp. 1232, 1235-6 (N.D. Ga. 1969), and Bowe v. Colgate-Palmolive Co., 272 F. Supp. 332, 339 (S.D. Ind. 1967).

139 Mickel v. South Carolina State Employment Service, 377 F.2d 239 (4th Cir.), cert. denied, 389 U.S. 877 (1967) (attempt to join employer utilizing employment service); Mondy v. Crown Zellerbach, 271 F. Supp. 258 (E.D. La. 1967), rev'd on other grounds sub nom. Oatis v. Crown Zellerbach, 398 F.2d 496 (5th Cir. 1968) (attempt to join international union to local); Sokolowski v. Swift \& Co., 286 F. Supp. 775 (D. Minn. 1968) (attempt to join international union to local); Cox v. United States Gypsum, 284 F. Supp. 74 (N.D. Ind. 1968) (attempt to join union to employer) aff'd 409 F.2d 289 (7th Cir. 1969); Moody v. Albemarle Paper, 271 F. Supp. 27 (E.D.N.C. 1967) (attempt to join international union to local); Freese v. John Morrell \& Co., $60 \mathrm{CCH}$ Lab. Cas. If 9231 (S.D. Iowa 1966) (attempt to join union to employer).

140 See FED. R. Crv. P. 19(b).

141 E.g., Miller v. International Paper Co., 408 F.2d 283, 285 (5th Cir. 1969): “The effect of a contrary holding would be virtually to eliminate the commission established by Congress to encourage fair employment practices."

142 SOVERN, supra note 76 , at $19-20$. 
Title VII allowing members of the EEOC to bring charges themselves $^{143}$ is also of major importance; state experience has disclosed the handicaps of relying solely on filed complaints. ${ }^{144}$

Where both section 1981 and Title VII are available, a plaintiff is far more likely to proceed under the 1964 act. The filing procedures are very simple and the complainant will not need the assistance of a lawyer. After a charge is filed, the EEOG carries the initiative for all proceedings until a no-cause finding is reached or conciliation efforts are terminated. Thus, the complainant's commitment is minimal both in time and money. Not only are these simple procedures likely to create extensive word of mouth publicity, but all employers subject to the act are required to post informational posters approved by the Commission. 145

Because the EEOC need only find "reasonable cause" to believe that a charge is true in order to commence conciliation proceedings, ${ }^{\mathbf{1 4 6}}$ many persons may receive partial satisfaction from conciliation in cases which would be lost in court. When the complainant has a strong enough case to justify going to trial he may be able to obtain a satisfactory conciliation agreement at far less trouble and expense. ${ }^{147}$ Even if conciliation is not successful the complainant may receive partial satisfaction if his complaint leads to a civil suit by the Attorney General. ${ }^{148}$

Last, except for avoiding a delay of up to 120 days, ${ }^{149}$ the plaintiff who has a choice of proceeding under either statute can accomplish nothing under section 1981 which he cannot under Title VII. Since the plaintiff's suit is not barred by failure of the EEOC to make a reasonable cause finding ${ }^{150}$ or to attempt conciliation, ${ }^{151}$ or by his

14342 U.S.C. § 2000e-5(a) (1964).

144 Sovern, supra note 76, at 83-90; P. NORGRen \& S. Hill, Toward Fatr EMrloyment 251-2 (1964); Hearings on H.R. 405, supra note 66, at 146-7.

14542 U.S.C. $\$ 2000 \mathrm{e}-10$ (1964).

14642 U.S.C. \& 2000e-5(a) (1964).

147 In fiscal $1967,43 \%$ of the complainant's cases resulted in fully or partially successful conciliations. EEOC, SECOND ANNUAL REPORT 9 (1968).

148 The Attorney General is empowered to bring suits against employers if he has reasonable cause to believe that they are engaging in a pattern or practice of discrimination. 42 U.S.C. $\$ 2000 \mathrm{e}-6(\mathrm{a})$ (1964). After conciliation efforts are unsuccessfully terminated by the EEOC, the case files are reviewed by the Commission and those which appear to evidence a continuing pattern or practice of discrimination are referred to the Attorney General under the authority of 42 U.S.C. $\S 2000 \mathrm{e}-4($ (f)(6) (1964). See 29 G.F.R. $\& 1601.26$ (1968).

14942 U.S.C. $\$ 2000$ e-5(e) (1964).

150 Edwards v. North American Rockwell, 291 F. Supp. 199 (C.D. Calif. 1968); Carrington v. Douglas Aircraft, 59 CCH Lab. Cas. I 9168 (C.D. Galif. 1968); Robinson v. P. Lorillard Co., C.A. No. C-141-G-66 (M.D.N.C. 1967) (unreported); Hall v. Werthan Bag, 251 F. Supp. 184 (M.D. Tenn. 1966); see Miller v. International Paper Co., 408 F.2d 283 (5th 
own refusal to accept a conciliation agreement, ${ }^{152}$ the only thing that stands between him and the courts is the statutory waiting period. Therefore, if direct access to the courts will mean the death of the Commission, the contribution made by section 1981 will be too insignificant to constitute a proximate cause.

Gir. 1969); Carr v. Conoco Plastics, 295 F. Supp. 1281 (N.D. Miss. 1969); Rosenfeld v. Southern Pacific Co., 293 F. Supp. 1219 (C.D. Calif. 1968); Hart v. Buckeye Industries, $59 \mathrm{CCH}$ Lab. Cas. I 9181 (S.D. Ga. 1968); King v. Georgia Power, 295 F. Supp. 943 (N.D. Ga. 1968). Contra, Bowe v. Colgate-Palmolive Co., 272 F. Supp. 332 (S.D. Ind. 1967). The Bowe case is of questionable precedent value since the only case cited in support is Hall v. Werthan Bag, supra.

151 See note 95 supra and accompanying text.

152 See note 96 supra and accompanying text. 